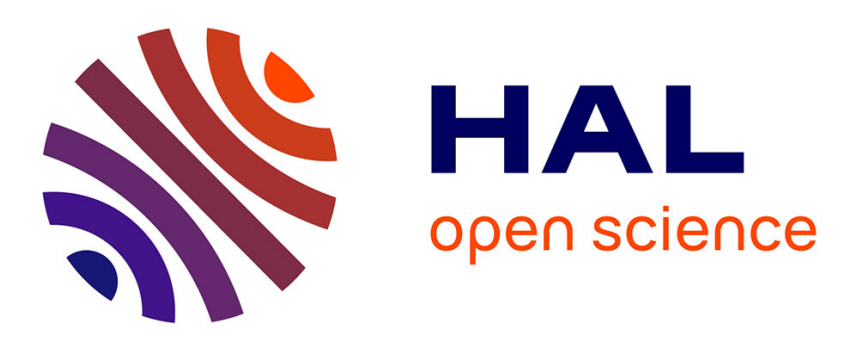

\title{
Impact of local slope and aspect assessed from LiDAR records on tree diameter in radiata pine (Pinus radiata D. Don) plantations
}

Hanieh Saremi, Lalit Kumar, Russell Turner, Christine Stone, Gavin Melville

\section{- To cite this version:}

Hanieh Saremi, Lalit Kumar, Russell Turner, Christine Stone, Gavin Melville. Impact of local slope and aspect assessed from LiDAR records on tree diameter in radiata pine (Pinus radiata D. Don) plantations. Annals of Forest Science, 2014, 71 (7), pp.771-780. 10.1007/s13595-014-0374-4 . hal01102800

\author{
HAL Id: hal-01102800 \\ https://hal.science/hal-01102800
}

Submitted on 13 Jan 2015

HAL is a multi-disciplinary open access archive for the deposit and dissemination of scientific research documents, whether they are published or not. The documents may come from teaching and research institutions in France or abroad, or from public or private research centers.
L'archive ouverte pluridisciplinaire HAL, est destinée au dépôt et à la diffusion de documents scientifiques de niveau recherche, publiés ou non, émanant des établissements d'enseignement et de recherche français ou étrangers, des laboratoires publics ou privés. 


\title{
Impact of local slope and aspect assessed from LiDAR records on tree diameter in radiata pine (Pinus radiata D. Don) plantations
}

\author{
Hanieh Saremi • Lalit Kumar • Russell Turner • \\ Christine Stone • Gavin Melville
}

Received: 21 November 2013 / Accepted: 25 March 2014 / Published online: 16 April 2014

(C) INRA and Springer-Verlag France 2014

\begin{abstract}
- Context Reliable information on tree stem diameter variation at local spatial scales and on the factors controlling it could potentially lead to improved biomass estimation over pine plantations.

- Aims This study addressed the relationship between local topography and tree diameter at breast height (DBH) within two even-aged radiata pine plantation sites in New South Wales, Australia.

- Methods A total of 85 plots were established, and 1,302 trees were sampled from the two sites. Airborne light

\section{Handling Editor: Aaron R. Weiskittel}

Contribution of the co-authors Coordinating the research project: Lalit Kumar and Russell Turner

Designing the experiment: Hanieh Saremi, Lalit Kumar and Russell Turner

Writing the manuscript: Hanieh Saremi and Christine Stone

Manuscript preparation and discussion of the results: Hanieh Saremi, Christine Stone, Lalit Kumar, Russell Turner and Gavin Melville

Running the data analysis: Gavin Melville

Collecting data: Hanieh Saremi, Russell Turner and Christine Stone

Providing knowledge of the study area: Christine Stone
\end{abstract}

\section{H. Saremi $(\bowtie) \cdot$ L. Kumar}

Ecosystem Management, School of Environmental and Rural

Science, University of New England, Armidale, New South Wales,

Australia

e-mail: hsaremi@myune.edu.au

\section{R. Turner}

Remote Census Pty Ltd, Morisset, New South Wales, Australia

\section{Stone}

Forest Science, New South Wales, Department of Primary Industries, Parramatta, New South Wales, Australia

\section{G. Melville}

New South Wales Department of Primary Industries, Trangie

Agricultural Research Centre, New South Wales, Australia detection and ranging (LiDAR) was used to derive slope and aspect and to link them to each individual tree.

- Results The results showed a significant relationship between DBH and local topography factors. At both sites, trees on slopes below $20^{\circ}$ and on southerly aspects displayed significantly larger DBHs than trees on steeper slopes and northerly aspects. Older trees with similar heights also exhibited a significant relationship between DBH and aspect factor, where greater DBHs were found on southerly aspects.

- Conclusions The observed correlation between tree DBH and LiDAR-derived slope and aspect could contribute to the development of improved biomass estimation approaches in pine plantations. These topographical variables are easily attained with airborne LiDAR, and they could potentially improve DBH predictions in resource inventories (e.g. stand volume or biomass) and support field sampling design.

Keywords Topography $\cdot$ LiDAR-derived metrics $\cdot$ Height classes · Canopy height model · Digital elevation model · Mixed linear models

\section{Introduction}

There are increasing demands on softwood plantation owners for improved estimates of standing timber and carbon inventories as well as continued pressure to develop more cost-effective resource assessment methodologies. Accounting for stand variability within plantation compartments will improve the accuracy of volume and biomass estimates. There is also strong motivation to improve sampling design efficiencies, thereby minimising the number of labour-intensive, measured plots while maximising predictive performance. One approach to achieving these aims is the identification of measurable, environmental factors that are well correlated to the stand variables of interest. Use of these auxiliary variables will improve efficiencies in both sampling 
design (e.g. through stratification) and estimation (e.g. through the use as covariates in the postulated model) (Hawbaker et al. 2009; Junttila et al. 2013; Maltamo et al. 2011). The aim of stratified estimation is to aggregate observations of the response variable into groups or strata that are more homogeneous than the population as a whole.

Traditionally, stem diameter at breast height (DBH) has been a widely used variable in volume and biomass allometric equations (e.g. Jenkins et al. 2003; Moore 2010) due to its relative ease of measurement in plots. For example, hundreds of different equations have been identified for estimating aboveground biomass but are usually applied on a species- and site-specific basis because of the influence of environmental conditions such as elevation, topography and soil factors on tree structure and growth. Specifically, a number of studies have noted the importance of spatial variation in local climatic and soil properties on the growth of radiata pine (Pinus radiata. D. Don) (e.g. Álvarez et al. 2013; Snowdon et al. 1998). Álvarez et al. (2013) concluded that the inclusion of some environmental variables such as water balance index (which takes into account variables such as precipitation, soil water content and transpiration) into Chilean $P$. radiata growth and yield models should improve the performance of local yield models. However, these soil properties can be difficult to characterise and map accurately, while the climatic variables are mapped at a relatively coarse spatial resolution ( $>250 \mathrm{~m}$ ). In addition, Turner et al. (2001) stated that at the broader scale, climatic and elevation variables are the most significant, but at a smaller scale, soils and topographical factors are of greater significance.

Interest continues to develop amongst Australia and plantation growers, and elsewhere, in identifying the benefits of integrating data acquired from airborne light detection and ranging (ALS or LiDAR) into their planning and operational systems, in particular in operational forest inventory applications (Schröder et al. 1998; White et al. 2013). LiDAR systems are active remote sensing devices that measure the time of travel needed for a pulse of laser energy sent from the airborne system to reach the ground and reflect back to the sensor. The time measurement is converted into a distance measurement that is used to derive a precise, high-spatial resolution, three-dimensional characterization of reflecting surfaces including the ground and forest vegetation (Popescu 2007). Several free and easy to use software packages are now available that efficiently process the LiDAR point data and produce a series of spatial products including accurate digital elevation models (DEMs) and canopy height model (CHM) (e.g. LAStools 2014; McGaughey 2013). The DEMs derived from LiDAR have become a readily available source of digital terrain information including high-spatial resolution maps of slope and aspect. These software packages can generate a wide range of LiDAR height and density metrics which can be used with co-located ground measures data to build predictive models of forest attributes (e.g. White et al. 2013).
Also, the resolution of the LiDAR point data is such that it is also possible to identify individual trees in the imagery. These LiDAR-derived products and software tools therefore present an efficient means of investigating the influence of topography on stem DBH at the intra-compartment scale.

The purpose of this study was to determine whether DBH of radiata pine trees within even-aged compartments, with relatively homogeneous environmental factors, showed a relationship with LiDAR-derived slope and aspect. The null hypotheses for this study were that slope and aspect had no effect on DBH variations. Taller trees naturally tend to have larger DBHs (Silvergieter and Lank 2011; Vanclay 2009); hence, there is a direct relationship between height and DBH. Consequently, to exclude height as an influencing factor, in the second section of this study, the effect of topography on DBHs of similar height trees was examined.

\section{Methods}

\subsection{Study area}

This study was carried out in two even-aged stands of radiata pine plantations in the Hanging Rock State Forest, near the town of Nundle in the northern tablelands of New South Wales (NSW), Australia (Fig. 1). The Hanging Rock State Forest is located in an undulating plateau and has a hilly topography with a mean elevation of $1,090 \mathrm{~m}$. The average annual rainfall is approximately $1,050 \mathrm{~mm}$. The mean elevation and annual rainfall estimates were obtained by the BIOCLIM variables derived using ANUCLIM 6.1 software (Xu and Hutchinson 2011). The fertile Tertiary basalt soils on the plateau are rich in nutrients (Ryan and Holmes 1986). Two sites were selected for this study: (1) a 34-year-old-age class established in 1977 and (2) a 9-year-old-age class planted in 2002. The initial stocking rate in the 1977 and 2002 sites were approximately 1,300 and 1,000 stems per hectare, respectively, and no silvicultural thinning events were undertaken at the sites; however, due to the patchy establishment, it has resulted in irregular stem density in trees in recent years (Table 1). The elevation ranged from 1,200 to $1,253 \mathrm{~m}$ in the 1977 site and from 1,256 to $1,280 \mathrm{~m}$ in the 2002 site. The original source of seedlots planted in 1977 site was from the Tallaganda open pollinated clonal seed orchard from NSW select material (Fielding 1964). Seed for the 2002 site was classed as GF19 (also open pollinated clonal seed orchard material) developed by the Radiata Pine Breeding Company (RPBC 2002) in New Zealand. The 1977 site was considered the first rotation plantation, while the 2002 site as the second rotation. Prior to the establishment of the 1977 site, the original native trees were harvested (in accordance with the codes of practice in place at that time) and the remaining vegetation and woody debris were pushed into windrows and later burnt. Cultivation consisted of deep 


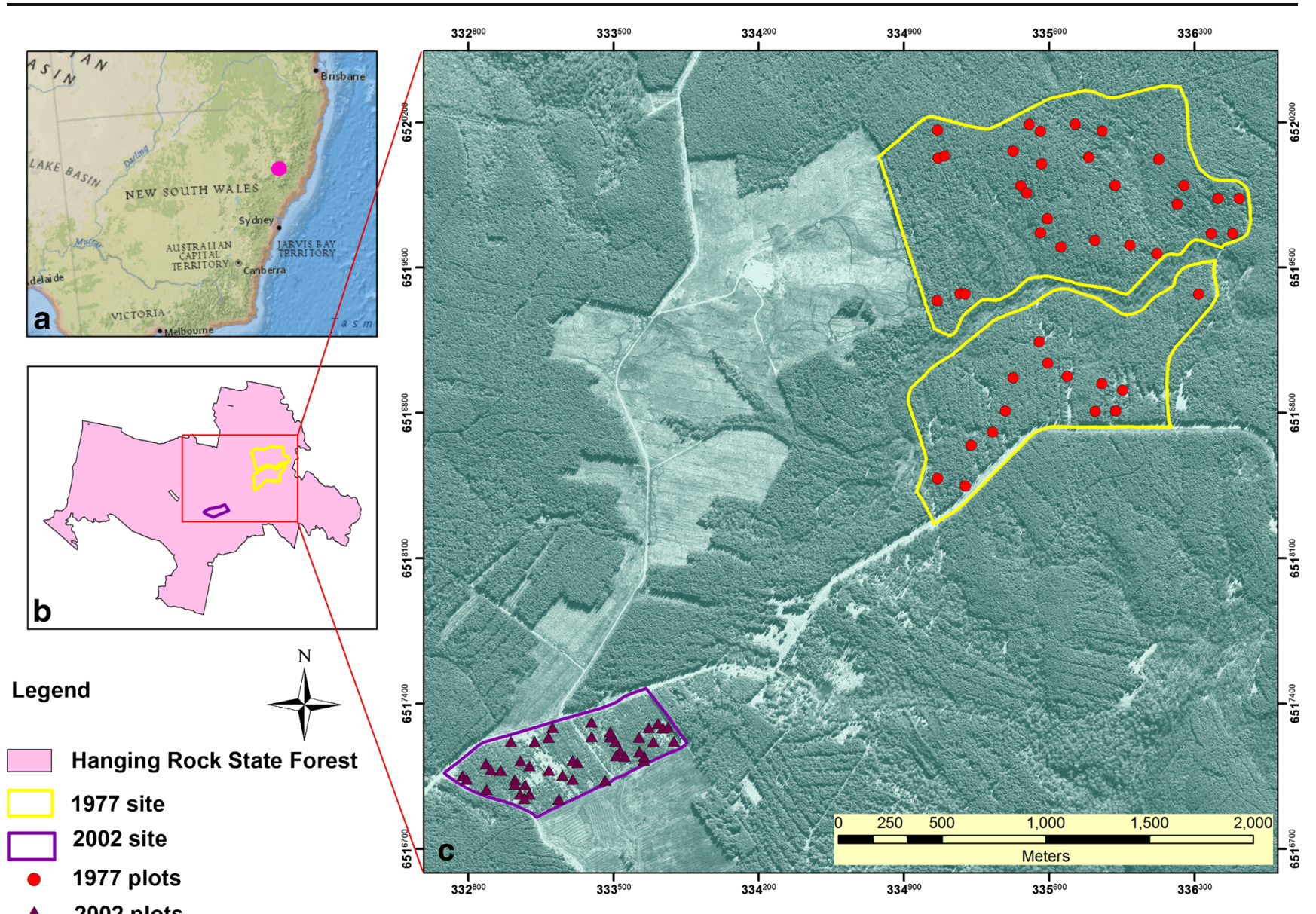

\section{- 2002 plots}

Fig. 1 a The study area in New South Wales, Australia. b The Hanging Rock State Forest and the extent of the two study areas. c A WorldView-2 (2011) image showing the location of the plots at each study site; a total of

rippling, with the riplines following the contour lines as close as possible and seeds were then planted at a stocking of approximately 1,300 stems per hectare. Three months before planting, there was a single broadcast application of a broadspectrum herbicide mixture (glyphosate and metsulfuron) which was applied at a rate according to the registered label instructions for the control of grasses, broad-leaf and wood weeds. In the 2002 site, the first rotation trees were harvested and the remaining slash and vegetation were windrowed and burnt; following the harvesting, the site was left fallow for 12 months before ripping and planting the site at a stocking of
42 and 43 plots were selected in the 1977 and 2002 sites, respectively. The large light blue-green patches are recently harvested areas

1,000 stems per hectare. Similar to the 1977 site, a single herbicide application was applied (not broadcast) along the ripped planting lines before planting. A post-plant herbicide was not applied to either stands. The main weedy vegetation types in the younger stand were native grasses and blackberries (Rubus fructicosus), and the most common weedy vegetation types in the older site were small wattle (Acacia spp.) trees. Originally for the 1977 stand, no fertiliser was applied at the time of planting and after establishment; however, after 1991, the forestry agency started to apply $50 \mathrm{~g}$ of monoammonium phosphate (MAP) with each seedling at planting.

Table 1 Summary of the field data collected in this study

\begin{tabular}{llllllllllll}
\hline $\begin{array}{l}\text { Study } \\
\text { site }\end{array}$ & $\begin{array}{l}\text { Land cover } \\
\text { type }\end{array}$ & $\begin{array}{l}\text { Initial } \\
\text { stocking } \\
\left(\text { stems ha }{ }^{-1}\right)\end{array}$ & $\begin{array}{l}\text { Stocking } \\
\text { range in } 2011 \\
\left(\text { stems ha }^{-1}\right)\end{array}$ & $\begin{array}{l}\text { Basal area } \\
\left(\mathrm{m}^{2} \mathrm{ha}^{-1}\right)\end{array}$ & $\begin{array}{l}\text { Mean } \\
\text { elevation } \\
(\mathrm{m})\end{array}$ & $\begin{array}{l}\text { Area } \\
(\text { ha) })\end{array}$ & $\begin{array}{l}\text { No. of } \\
\text { plots }\end{array}$ & $\begin{array}{l}\text { No. of } \\
\text { trees }\end{array}$ & $\begin{array}{l}\text { Mean tree } \\
\text { DBH }(\mathrm{cm})\end{array}$ & $\begin{array}{l}\text { Mean } \\
\text { dominant } \\
\text { height }(\mathrm{m})^{\mathrm{a}}\end{array}$ & $\begin{array}{l}\text { Mean tree } \\
\text { height (m) } \\
(\mathrm{selected} \mathrm{trees})\end{array}$ \\
\hline 2002 & $\begin{array}{l}\text { 9-year-old forest } \\
1,000\end{array}$ & $100-987$ & 17.71 & $1,270.4$ & 36 & 43 & 629 & 17.75 & 11.62 \\
1977 & 34-year-old forest & 1,300 & $48-675$ & 120.98 & $1,231.9$ & 215 & 42 & 673 & 45.8 & 37.29 & 35.41 \\
\hline
\end{tabular}

${ }^{\mathrm{a}}$ The MDH of the trees was calculated using spatial stratification and dividing each plot into four smaller areas (subplots) within which the highest LiDAR return point was found. These heights are then averaged to obtain a stratified dominant height estimate (Næsset 1997) 


\subsection{Field survey data}

The ground survey plots used in this study were initially established for another study by the New South Wales Department of Primary Industries and the Forestry Corporation NSW (FCNSW). These plots were primarily stratified using focal-based stand level metrics extracted from a LiDARderived CHM with $1 \mathrm{~m}$ pixel resolution. The CHM is generated by subtracting the elevation of the interpolated ground surface (DEM) from the elevation of the upper canopy surface (sometimes referred to as a digital surface model or DSM). Metrics which were used for the stratification included the mean dominant height (MDH), which was based on the mean height of pixels extracted via a $5 \times 5 \mathrm{~m}$ local maxima search, and the stocking rate. In total, 55 plots in the 1977 site and 53 plots in the 2002 site were established.

However, as the main aim of the study was DBH and topographical analysis, only those plots and trees within the plots boundary in the field that could be accurately identified and matched within the LiDAR data were selected. As a result, a total of 42 and 43 plots were selected in the 1977 and 2002 sites, respectively. The plot sizes ranged from a radius of 11.28 to $19.96 \mathrm{~m}$ in the 1977 site and from 7.98 to $17.84 \mathrm{~m}$ radius in the 2002 site, depending on the density of trees. These circular plots not only represented the different vegetation structures but also covered a range of topographical variation. In the 1977 site, half of the plots were located on south-facing aspects $\left(90^{\circ}-270^{\circ}\right)$ and the other half on north-facing aspects $\left(270^{\circ}-\right.$ $90^{\circ}$ ). The same was true for the 2002 site, where 22 plots were located on north-facing aspects and 21 plots on south-facing aspects. The distribution of these plots, based on slope parameters, is available in Table 2, indicating substantial variation in topography distribution at both sites.

The DBHs of all the trees in each plot were measured with a diameter tape; overall, 673 trees in the 1977 site and 629 trees in the 2002 site were measured. Additionally, in each plot, an average subset of five to six trees were selected, and their heights were measured with a digital hypsometer (Haglöf Vertex IV Hypsometer, Sweden), with the average of three readings being recorded. Plot locations were provided as GPS waypoints and also manually confirmed in the field by interpretation of LiDAR height imagery. Two GPS units were used for this study, the ScoutPak GPS system (Juniper Systems and OnPOZ Precision Positioning, Logan, Utah, USA) and the

Table 2 The distribution of plots based on slope parameters in both study sites

\begin{tabular}{lllll}
\hline Study site & \multicolumn{2}{l}{ Slope classes } & \\
\cline { 2 - 4 } & $<10^{\circ}$ & $10-20^{\circ}$ & $>20^{\circ}$ & Total plots \\
\hline 2002 & 18 & 8 & 17 & 43 \\
1977 & 15 & 10 & 17 & 42 \\
\hline
\end{tabular}

Garmin Oregon $^{\circledR} 550$ (Garmin International). Table 1 summarises the field data collected at each study site.

\subsection{LiDAR data}

Airborne LiDAR survey of the Hanging Rock State Forest was acquired in June 2011 using a Trimble Harrier 68i system mounted on a Cessna U206G airplane. The reference coordinate system used in this study was the Map Grid of Australia (MGA) with the Geocentric Datum of Australia (GDA94) in the Universal Transverse Mercator (UTM) Zone 56 projection. The LiDAR specifications are summarised in Table 3. The LiDAR points were captured, processed, geo-referenced and classified by Terranean Mapping Technologies Pty Ltd into ground and non-ground categories using MARSÒ software (Merrick and Company).

\subsection{Data preparation and analysis}

The extraction and processing of topographic parameters from LiDAR were conducted using FUSION software and LDV visualising system, created by the US Forest Service (McGaughey 2007). Since plot level aspect and slope are required, reasonably high-resolution DEMs were created from the LASer file format (LAS) ground point cloud data for each study site, $5 \mathrm{~m}$ resolution for the 1977 site and $3 \mathrm{~m}$ for the 2002 site. The DEMs were calculated via bilinear

Table 3 LiDAR survey specification

\begin{tabular}{ll}
\hline Data acquisition & Survey design \\
\hline Flying height & $1,000 \mathrm{~m}$ \\
$\begin{array}{l}\text { Flying speed } \\
\text { Navigation system }\end{array}$ & $\begin{array}{c}\text { Applanix POS/AV 410 Inertial } \\
\text { Motion System and 12 channel, } \\
\text { dual frequency GPS }\end{array}$ \\
Platform & Cessna U206G \\
LiDAR system & Trimble Harrier 68i, with a Rollie 39 \\
& mega-pixel camera (RGB only) \\
Pulse rate & $200 \mathrm{kHz}^{-1}$ \\
Scan rate & $81 \mathrm{~Hz}$ \\
Scanning angle & $\pm 30^{\circ}$ from Nadir \\
Swath overlap & $40 \%$ \\
Capture pulse density & $2.03 \mathrm{~m}^{-2}$ within swath \\
Average pulse density & $3.65 \mathrm{~m}^{-2}$ (including $40 \%$ overlap) \\
Spot footprint & $0.50 \mathrm{~m}^{2}$ \\
Spatial reference framework & \\
Horizontal datum & GDA94 \\
Vertical datum & AHD \\
Map projection & MGA zone 56 \\
Geodetic datum & AusGeoid 98 \\
\hline
\end{tabular}


interpolation. Kraus and Pfeifer (1998) have described the algorithm used to generate the bare earth surface.

Several topographic layers, such as slope, aspect and hillshade, were produced from these bare earth DEMs in GIS software (ArcGIS 10, ESRI). For topographical variables, three slope classes including class $1\left(0^{\circ}-10^{\circ}\right)$, class $2\left(10^{\circ}-20^{\circ}\right)$ and class $3\left(>20^{\circ}\right)$ and two aspect classes, specifically northerly (sites with aspects between $270^{\circ}$ and $90^{\circ}$ including) and southerly aspects (sites with aspects between $90^{\circ}$ and $270^{\circ}$ ), were categorised. The topographical variables were then extracted at plot level. The plots and the trees within the plots that could be located in LiDAR (with the aid of GPS locations, hardcopy maps and canopy gaps) were then matched to the topographical variables using ArcGIS software, and the relationships between tree DBH in each plot and topography variables were examined. To facilitate the process, FUSION "plot mode" was used, which defines a buffer around the plot centre coordinates and includes all the trees from the buffer in a data subset, based on each plot radius (m).

\subsubsection{Mixed linear models}

Mixed linear models were used to determine whether slope and aspect had a significant influence on DBH. The mixed linear models associated one continuous dependent variable with several explanatory variables. These models contain both fixed and random effects parameters and estimate the variance components (between and within) simultaneously and in a more efficient way (Burton et al. 1998) than fixed effect models. The mixed model was fitted using the residual maximum likelihood (REML) method. Plot number was fitted as a random factor, while slope and aspect were included as fixed effects in the model. The $R$ package Asreml-R, which is implemented in the $R$ statistical software package (R Development Core Team 2011), was used for the analysis (version 3.0.1). The error distribution was assumed to be Gaussian. Statistical significance for fixed effects was obtained using the Wald statistic. Statistical significance for random effects was obtained by comparing twice the change in log likelihood, which occurs when the random effect is fitted, to a chi-square variate on $k$ degrees of freedom where $k$ is the number of additional random parameters. The residual values from the models were inspected to confirm that the assumptions of normality and constant variance were satisfied. Elevation was initially included at both sites; however, since the range is less than $\pm 100 \mathrm{~m}$, it showed no significant relationships and was therefore excluded from the model.

\subsection{The DBH comparison within height classes}

The effect of topographic variables on DBH was examined within different height classes. As mentioned previously, five to six trees were selected from each plot and their heights were measured in the field. With the help of two GPS (horizontal accuracy of around $\pm 5 \mathrm{~m}$ ), crown interpretation and canopy gap arrangements of these trees were located and matched to the LiDAR data. Only those trees in the field that were accurately identified in the LiDAR data were selected, and their topographical attributes were identified. Where there was doubt, features were not matched. Detecting and distinguishing the competing vegetation was not an issue in the detection process of radiata pine trees with LiDAR. As mentioned previously, the most common weed in the 1977 site were small wattle trees, and since their heights were less than half the height of the mature radiata pine trees, the pine trees were easily detected. Also in the 2002 site, the height of the main weedy vegetation (blackberries and native grasses) rarely exceeded $1.5 \mathrm{~m}$, which made the radiata pine to be distinguished easily. A total of 193 trees in the 1977 site and 254 trees in the 2002 site were identified. Different metrics including height (the difference between local maxima and local minima), coordinate system and elevation were recorded for each individual tree in LDV using the LiDAR point cloud. The LiDAR extracted tree heights were compared with the measured field heights, and the results showed a high correlation between the heights at both study sites $\left(R^{2}=0.90\right.$ and $\mathrm{RMSE}=0.66$ for 2002 and $R^{2}=0.87$ and $\mathrm{RMSE}=1.49$ for 1977 sites). Based on these results, LiDAR heights were used for the DBH comparison performance.

From the LAS ground point cloud data, high-resolution DEMs were created for each study site, $1 \mathrm{~m}$ resolution for the 1977 site and $0.5 \mathrm{~m}$ for the 2002 site. The GIS-derived layers were used to allocate a slope and aspect class to each individual tree. Based on the trees aspect position, trees were first categorised into two groups (north and south). Table 4 provides the tree classification based on the aspect classes in both study sites. Trees in each aspect group were then categorised into height subclasses. For the younger stand, trees were allocated into eight height classes based on a $0.5 \mathrm{~m}$ interval, while trees in the older stand were divided into nine height classes based on a $1 \mathrm{~m}$ interval. The mean DBHs of trees within each height subclass in both northern and southern aspects were compared to verify whether aspect had an influence on the DBH of trees with similar heights.

For slope classification, a similar approach was undertaken; the trees at both sites were categorised into two groups:

Table 4 Tree classifications for DBH comparison within height classes based on aspect and slope parameters in both study sites

\begin{tabular}{lllllll}
\hline Study site & \multicolumn{2}{c}{ Aspect classes } & Total trees & \multicolumn{2}{l}{ Slope classes } & \multirow{2}{*}{ Total trees } \\
\cline { 2 - 3 } & North & South & & $<20^{\circ}$ & $>20^{\circ}$ & \\
\hline 2002 & 147 & 107 & 254 & 70 & 184 & 254 \\
1977 & 100 & 93 & 193 & 133 & 60 & 193 \\
\hline
\end{tabular}


less than $20^{\circ}$ and greater than $20^{\circ}$ (Table 4). Since fewer trees were found in slope categories between $10^{\circ}$ and $20^{\circ}$, they were included in the $0^{\circ}-10^{\circ}$ slope category. Here again, the mean DBHs of the trees in the same height subclasses were calculated and compared.

Mixed linear models were used again to assess the relationship between the DBH of these trees and height classes along with the topography factors. In the model, DBH was included as the dependant variable, plot number as a random effect and slope and aspect were included as fixed effects. The midpoints of each height class were included as a covariate. To smooth out some of the variation between height categories, height classes were also defined as a random factor. While the numbers of trees in each subclass were not the same, the overall sample size was deemed to be large enough so that the difference in sample sizes did not affect the results.

\section{Results}

\subsection{Effect of slope and aspect on DBH}

\subsubsection{The 1977 site}

Slope and aspect had a highly significant effect on $\mathrm{DBH}$, while there was no interaction between the two factors (Table 5).

$\mathrm{DBH} \approx$ Slope + Aspect $+($ Slope $\times$ Aspect $)+\operatorname{random}($ plot $)$

The mean DBHs were larger on southerly aspects (Fig. 2a). A comparison between the three slope classes showed significant differences in DBH between class $1\left(<10^{\circ}\right)$ and the other classes, with larger values in class $1(55.1 \mathrm{~cm})$ compared to classes $2(48.7 \mathrm{~cm})$ and $3(45.2 \mathrm{~cm})$.

\subsubsection{The 2002 site}

Similar to the 1977 trees, analysis of variance in the 2002 site showed that slope and aspect had a highly significant effect on DBH; however, the interaction between slope and aspect was not significant (Table 6).

Table 5 ANOVA results of the effect of slope, aspect and their interaction on the DBH of trees in the1977 site

\begin{tabular}{lllcl}
\hline & Df. & Sum of sq. & Wald statistic & $P$ value (chi-square) \\
\hline Random plots & 1 & 119,440 & 907.50 & $<2.2 \mathrm{e}-16^{* *}$ \\
Aspect & 1 & 1,326 & 10.08 & $0.0015^{*}$ \\
Slope & 2 & 3,261 & 27.51 & $<1.063 \mathrm{e}-06^{* *}$ \\
Slope:aspect & 2 & 187 & 1.42 & 0.49223 \\
\hline
\end{tabular}

$* P<0.01$, significance level; $* * P<0.001$, significance level
The southerly aspect showed a higher DBH than the northerly aspect, and the differences were significant (Fig. 2b). In slopes less than $10^{\circ}$, the mean DBH was estimated as $22.67 \mathrm{~cm}$ and showed a significant difference to the mean DBHs in slopes greater than $20^{\circ}(19.52 \mathrm{~cm})$. However, no significant differences were seen between slope classes 1 and 2 and slope classes 2 and 3.

Overall, the ANOVA results at both sites showed a significant relationship between tree DBH and slope and aspect factors. Trees with greater DBHs were seen on southerly aspects and on slopes $<10^{\circ}$. Therefore, based on these results, the null hypothesis was rejected at the $1 \%$ level of significance.

3.2 The effect of slope and aspect on DBHs of similar height trees in the 1977 and 2002 sites

The ANOVA results of the 1977 site showed a significant effect of aspect on DBH; however, slope and the interaction between slope and aspect were not significant.

$$
\begin{aligned}
\mathrm{DBH} \approx \text { Height_class } & + \text { Slope }+ \text { Aspect }+(\text { Slope } \times \text { Aspect }) \\
& + \text { random }(\text { plot })+\text { random }(\text { Height_class })
\end{aligned}
$$

In the 2002 site, unlike the 1977 site, slope and aspect did not show any significant relationship with DBH (Table 7).

As mentioned previously, for both 1977 and 2002 sites, various height classes were defined. Figure 3 illustrates the predicted DBHs of trees, as obtained from the model, in each aspect and slope class. In the 1977 site, trees on the southerly aspects were seen to have greater DBHs. For the 2002 site, this trend was only seen in trees with heights less than $10.5 \mathrm{~m}$, while taller trees (height $>10.5 \mathrm{~m}$ ) with greater DBHs were mainly found on the northern aspects. Amongst slope classification, in the 1977 site, trees within the same height category displayed greater DBHs at the steeper slopes; however, in the 2002 site, trees in slopes lower than $20^{\circ}$ revealed higher mean DBHs. Although the DBH differences were usually not significant, with the exception of graph $4 \mathrm{a}$, the graphs show the underlying trends in the data and the differences could be significant if more plots were surveyed. The mean DBHs of the tree height categories are shown in the "Appendix".

\section{Discussion}

Our study demonstrated that local slope and aspect had a significant influence on DBH in two even-aged stands of $P$. radiata with relatively homogeneous environmental factors i.e. similar climatic and edaphic conditions and tree genetics. Slope and aspect explained DBH variations in most of the 

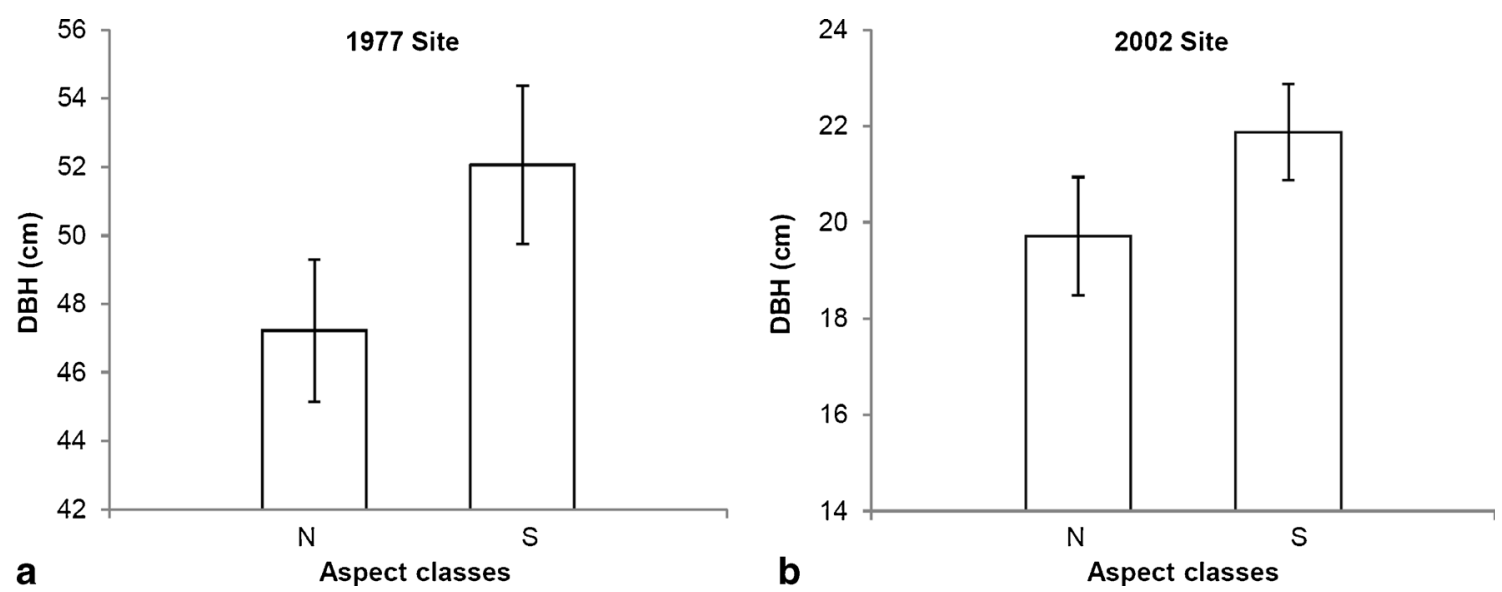

Fig. 2 Relationship between DBH and aspect for the two study sites. Bars indicate predicted mean DBH values in the two aspect classes at the a 1977 site and b 2002 site. Predictions are averaged over slope. Error bars represent \pm 1 standard error

trees in this study, wherein large DBH trees were common on gentle slopes $\left(<20^{\circ}\right)$ and on southerly aspects, while smaller trees were more frequent on slopes over $20^{\circ}$ and on northerly aspects. The comparison of DBH values within height classes of the 1977 site also revealed the effect of aspect on DBH. The trees on northern aspects showed lower DBHs, while those on southern aspect displayed a larger DBH. Even though significant differences were not seen within most of the height categories, the trend clearly shows the effect of aspect and slope on DBH.

Slope and aspect factors affect the amount of daily solar radiation as well as microclimate (Kumar et al. 1997). In addition, variable topography results in uneven availability of soil moisture and nutrients (Nevo 2001) and has been identified as a major driver of observed spatial variations in vegetation composition and structure (Chen et al. 2013). The presence of larger diameter radiata trees on southern aspects at both sites suggests adequate light and water availability compared to the northern aspect. In the northern hemisphere, southerly aspects receive as much as six times more solar radiation than northerly aspects and therefore experience higher evapotranspiration, drier and warmer and more variable microclimatic conditions (Auslander et al. 2003). Worrell and Malcolm (1990) reported that south-facing aspects in northern Britain were unfavourable for forest growth due to strong wind exposures and droughts. However, this trend is reversed in the

Table 6 ANOVA results of the effect of slope, aspect and their interaction on the DBH of trees in the 2002 site

\begin{tabular}{lllcl}
\hline & Df. & Sum of sq. & Wald statistic & $P$ value (chi-square) \\
\hline Random plots & 1 & $20,416.1$ & 767.73 & $<2.2 \mathrm{e}-16^{*}$ \\
Aspect & 1 & 314.3 & 11.82 & $0.00059^{*}$ \\
Slope & 2 & 819.3 & 30.81 & $<2.042 \mathrm{e}-07^{*}$ \\
Slope:aspect & 2 & 23.4 & 0.88 & 0.64394 \\
\hline
\end{tabular}

$* P<0.001$, significance level southern hemisphere, where northerly aspects receive more solar radiation than southerly aspects (Kumar et al. 1997).

Slope has also proven to act on dynamics and structure of forests such as tree growth, recruitment, competition and mortality (Robert 2003). Li et al. (2006) reported lower loss of water and nutrient in flat and gentle slopes, while several other studies reported reduced growth rates and increased rates of tree mortality on steep slopes $\left(>20^{\circ}\right)$ (e.g. Ferry et al. 2010; Lee et al. 2004). This is consistent with our results, where greater DBHs were seen on gentle slopes and southerly aspects (opposite of the northern hemisphere). In countries such as Australia and Chile, the availability of soil moisture is critical to growth performance, whereas in some regions of New Zealand, rainfall is non-limiting, but minimum temperatures have a greater influence on radiata growth. In our study, the two stands were at an elevation

Table 7 ANOVA results of the effect of slope, aspect and their interactions on DBHs of similar tree heights of both 193 trees in the 1977 site and 254 trees in the 2002 site

$\begin{array}{lll}\text { Df. Sum of sq. } & \begin{array}{l}\text { Wald } \\ \text { statistic }\end{array} & \begin{array}{l}P \text { value } \\ \text { (chi-square) }\end{array}\end{array}$

\begin{tabular}{lllll}
\hline 1977 site & & & & \\
Random plots & 1 & 162,220 & $2,806.21$ & $<2.2 \mathrm{e}-16^{* * *}$ \\
Random height class & 1 & 739 & 12.78 & $0.00035^{* * *}$ \\
Aspect & 1 & 304 & 5.26 & $0.02178^{*}$ \\
Slope & 1 & 109 & 1.89 & 0.16924 \\
Slope:aspect & 1 & 128 & 2.21 & 0.13728 \\
2002 site & & & & \\
Random plots & 1 & $16,736.3$ & $1,777.53$ & $<2.2 \mathrm{e}-16^{* * *}$ \\
Random height class & 1 & 63.1 & 6.70 & $0.009636^{* *}$ \\
Aspect & 1 & 0.1 & 0.01 & 0.91252 \\
Slope & 1 & 10.0 & 1.06 & 0.30234 \\
Slope:aspect & 1 & 2.6 & 0.28 & 0.59831 \\
\end{tabular}

$* P<0.05$, significance level; $* * P<0.01$, significance level; $* * * P<0.001$, significance level 


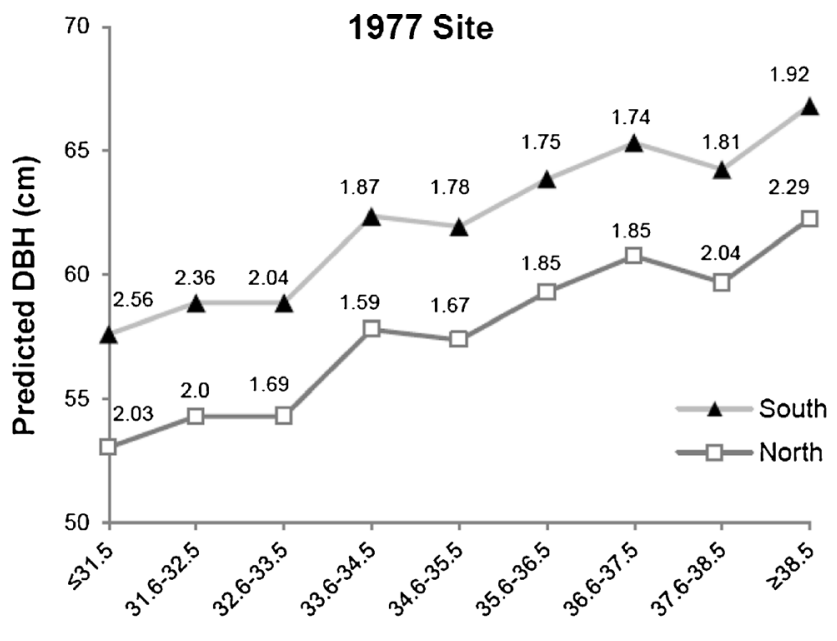

a

Midpoints of height subclasses (m)

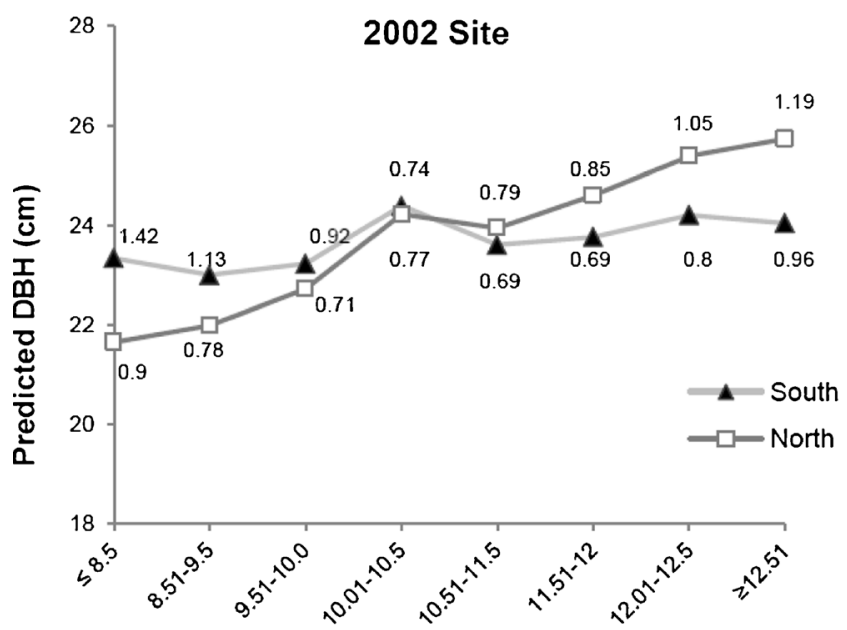

C

Midpoints of height subclasses (m)

Fig. 3 Relationship between DBH and height with slope and aspect for the two study sites. The predicted DBHs of each height subclass for different topographic categories are obtained using mixed linear models: a DBH vs height and aspect classes for the 193 trees at the 1977 site, b DBH vs height and slope classes for the 193 trees at the 1977 site, c DBH

of approximately $1,250 \mathrm{~m}$, with a mean annual rainfall of approximately $1,000 \mathrm{~mm}$ and without a distinct dry period. Nevertheless, the Hanging Rock plantation appears to have been subjected to periods of negative water balance, especially on the steeper slopes and northerly aspects, during the period since planting.

The observed correlation in variation between tree DBH and LiDAR-derived slope and aspect identifies the potential of these two topographical variables as suitable spatially explicit attributes for improving efficiencies of DBH-derived inventory attributes as well as in the sampling design. The benefits of incorporating of topographic slope and aspect into growth modelling have been demonstrated for several commercial species but not $P$. radiata (e.g. Stage and Salas 2007). Irrespective of the modelling approach taken, ground plots must
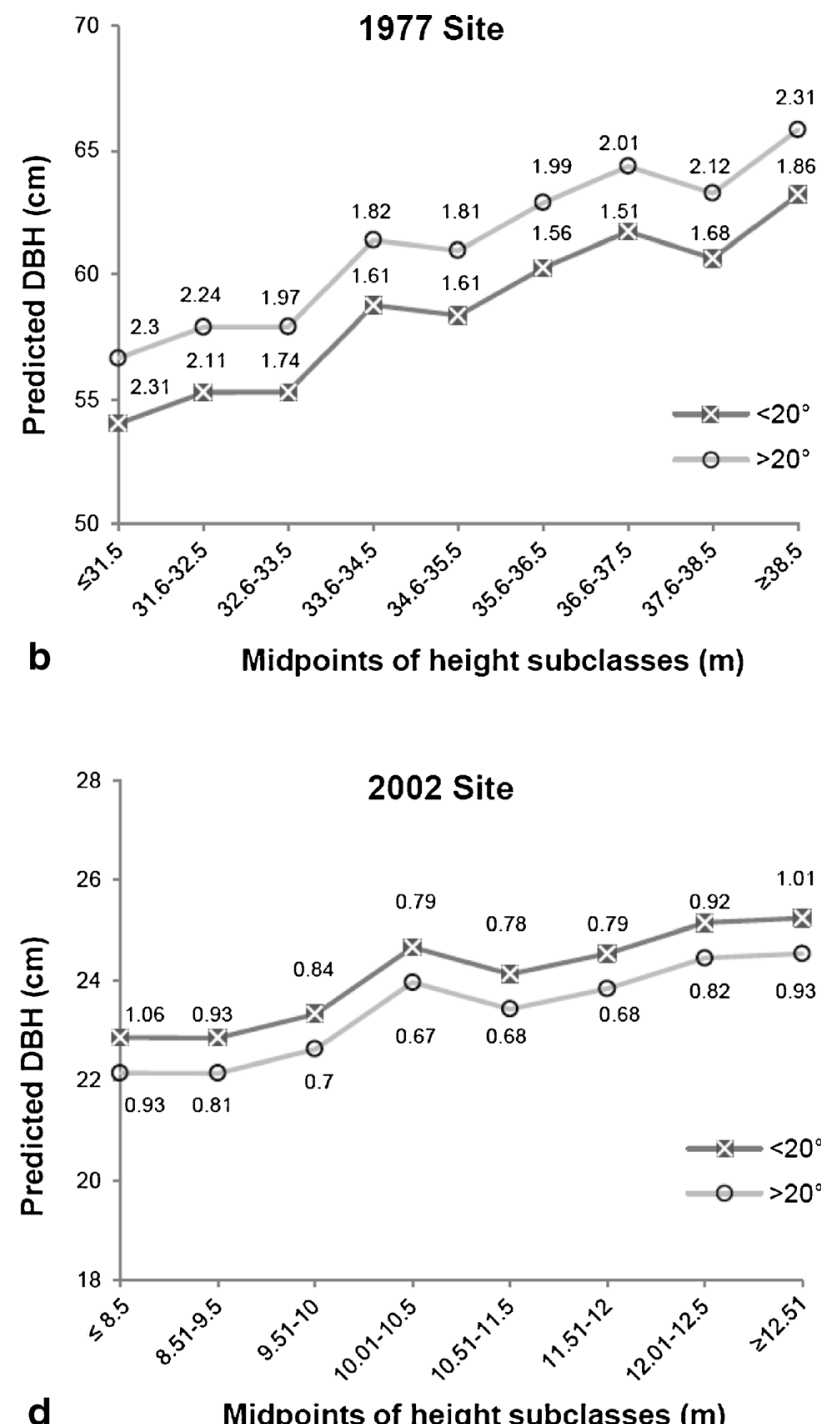

vs height and aspect classes for the 254 trees at the 2002 site and $\mathbf{d}$ DBH vs height and slope classes for the 254 trees in the 2002 site. The differences in DBHs are significant in graph $\mathbf{a}$; however, the differences in graphs $\mathbf{b}, \mathbf{c}$ and $\mathbf{d}$ are not significant. The standard error (SE) values are shown for each data point

represent the full range of variability of the inventory attributes of interest. The application of aspect and/or slope from a LiDAR DEM as a priori information to define strata within compartments would improve sampling efficiency and prediction accuracies of stand volume and biomass estimates. It is well established that LiDAR metrics derived from a CHM can be used to directly model these stand attributes (e.g. Gleason and $\operatorname{Im}$ 2012; Li et al. 2008); access to recent LiDAR coverage are not always available and hence the CHM becomes 'out-ofdate'. However, a highly detailed, bare earth DEM is available for continued use after the first LiDAR acquisition. Therefore, the use of slope and/or aspect derived from a LiDAR DEM as auxiliary variables may be a cheaper option for improving efficiencies in estimating volume or biomass in stands of $P$. radiata on varying topography. 


\section{Conclusion}

This study has shown that variation in individual $P$. radiata DBH is significantly influenced by local slope and aspect in a plantation on the northern tablelands of New South Wales. LiDAR DEM-derived aspect and slope can be easily attained and has accurate, high spatial resolution making it an excellent source of auxiliary information that can be used to improve the precision of stand inventory estimates (e.g. stand volume or biomass). Although DBH showed response to local topography, a similar evaluation needs to be done for tree heights to confirm the inclusion of these site parameters into a greater range of $P$. radiata allometric equations. Augmenting empirical stand growth models with environmental variables derived from GIS datasets have been commonly applied but at a relatively low spatial resolution (e.g. Woollons et al. 1997). The novelty of this study is that we have used LiDAR to show that radiata trees respond through differences in stem diameter to microsite differences in slope and aspect. This level of precision may not be required for plantation-level evaluations but would beneficial when undertaking stand-level inventories.

Acknowledgements The authors would like to thank the Forestry Corporation (Forestry Corporation NSW) New South Wales for providing the LiDAR data and the New South Wales Department of Primary Industries for the help in conducting the field surveys used in this study. We would like to express our deep graduate to the editors and the two anonymous reviewers for their constructive comments and suggestions to improve the quality of the paper.

\section{Appendix}

The mean (standard error) DBH of height classes at both sites

\begin{tabular}{|c|c|c|c|c|c|c|c|c|c|c|c|c|}
\hline \multirow[b]{2}{*}{ Height (m) } & \multicolumn{3}{|l|}{ North } & \multicolumn{3}{|l|}{ South } & \multicolumn{3}{|l|}{$>20^{\circ}$} & \multicolumn{3}{|l|}{$<20^{\circ}$} \\
\hline & $\begin{array}{l}\text { Tree } \\
\text { samples }\end{array}$ & $\begin{array}{l}\text { Mean } \\
\text { DBH }(\mathrm{cm})\end{array}$ & $\begin{array}{l}\text { Standard } \\
\text { error }\end{array}$ & $\begin{array}{l}\text { Tree } \\
\text { samples }\end{array}$ & $\begin{array}{l}\text { Mean } \\
\text { DBH }(\mathrm{cm})\end{array}$ & $\begin{array}{l}\text { Standard } \\
\text { error }\end{array}$ & $\begin{array}{l}\text { Tree } \\
\text { samples }\end{array}$ & $\begin{array}{l}\text { Mean } \\
\text { DBH }(\mathrm{cm})\end{array}$ & $\begin{array}{l}\text { Standard } \\
\text { error }\end{array}$ & $\begin{array}{l}\text { Tree } \\
\text { samples }\end{array}$ & $\begin{array}{l}\text { Mean } \\
\text { DBH }(\mathrm{cm})\end{array}$ & $\begin{array}{l}\text { Standard } \\
\text { error }\end{array}$ \\
\hline & \multicolumn{12}{|l|}{1977 site } \\
\hline$\leq 31.5$ & 15 & 53.61 & 2.10 & 1 & 56.50 & - & 11 & 53.31 & 2.83 & 5 & 54.86 & 1.47 \\
\hline $31.6-32.5$ & 6 & 54.95 & 3.09 & 3 & 63.67 & 2.28 & 3 & 63.67 & 2.28 & 6 & 54.95 & 3.09 \\
\hline $32.6-33.5$ & 18 & 53.83 & 1.40 & 3 & 54.73 & 4.24 & 7 & 55.94 & 2.47 & 13 & 53.03 & 1.62 \\
\hline $33.6-34.5$ & 21 & 57.13 & 2.14 & 7 & 66.64 & 7.50 & 11 & 64.86 & 5.66 & 17 & 56.05 & 1.62 \\
\hline $34.6-35.5$ & 14 & 52.09 & 2.77 & 9 & 66.17 & 2.59 & 10 & 62.83 & 3.31 & 14 & 53.46 & 2.86 \\
\hline $35.6-36.5$ & 5 & 59.82 & 1.79 & 16 & 63.70 & 2.75 & 4 & 69.85 & 5.71 & 17 & 61.11 & 2.28 \\
\hline $36.6-37.5$ & 10 & 61.65 & 3.71 & 18 & 64.93 & 1.78 & 3 & 70.02 & 10.40 & 25 & 62.99 & 1.57 \\
\hline $37.6-38.5$ & 7 & 56.16 & 2.64 & 15 & 60.89 & 1.46 & 5 & 57.12 & 4.28 & 17 & 60.05 & 1.28 \\
\hline \multirow[t]{2}{*}{$\geq 38.5$} & 4 & 65.7 & 7.01 & 21 & 64.61 & 1.64 & 6 & 71.95 & 2.38 & 19 & 62.52 & 1.83 \\
\hline & \multicolumn{12}{|c|}{2002 site } \\
\hline$\leq 8.5$ & 19 & 22.37 & 0.86 & 3 & 22.73 & 2.69 & 19 & 22.58 & 0.75 & 3 & 21.4 & 4.07 \\
\hline $8.51-9.5$ & 28 & 20.66 & 1.01 & 2 & 27.5 & 0.60 & 27 & 20.38 & 1.01 & 3 & 27.7 & 0.71 \\
\hline $9.51-10.0$ & 43 & 21.70 & 0.58 & 3 & 23.03 & 1.42 & 41 & 21.89 & 0.60 & 5 & 21.04 & 1.09 \\
\hline $10.01-10.5$ & 15 & 23.85 & 1.15 & 22 & 25.62 & 1.00 & 24 & 24.19 & 0.95 & 13 & 26.21 & 1.46 \\
\hline $10.51-11.5$ & 17 & 23.89 & 1.10 & 22 & 21.87 & 0.97 & 24 & 22.62 & 0.79 & 15 & 22.96 & 1.43 \\
\hline $11.51-12.0$ & 19 & 24.55 & 1.06 & 27 & 23.83 & 0.79 & 29 & 24.35 & 0.79 & 17 & 23.75 & 1.07 \\
\hline $12.01-12.5$ & 3 & 28.83 & 2.64 & 16 & 24.42 & 0.85 & 12 & 24.88 & 1.19 & 7 & 25.53 & 1.33 \\
\hline$\geq 12.51$ & 3 & 25.23 & 2.12 & 12 & 24.43 & 0.98 & 8 & 23.85 & 0.71 & 7 & 25.43 & 1.67 \\
\hline
\end{tabular}

\section{References}

Álvarez J, Allen HL, Albaugh TJ, Stape JL, Bullock BP, Song C (2013) Factors influencing the growth of radiata pine plantations in Chile. Forestry 86:13-26. doi:10.1093/forestry/cps072

Auslander M, Nevo E, Inbar M (2003) The effects of slope orientation on plant growth, developmental instability and susceptibility to herbivores. J Arid Environ 55:405-416
Burton P, Gurrin L, Sly P (1998) Extending the simple linear regression model to account for correlated responses: an introduction to generalized estimating equations and multi-level mixed modelling. Stat Med 17:1261-1291

Chen JM, Chen X, Ju W (2013) Effects of vegetation heterogeneity and surface topography on spatial scaling of net primary productivity. Biogeosciences 10:4879-4896. doi:10.5194/bg-10-4879-2013

Ferry B, Morneau F, Bontemps JD, Blanc L, Freycon V (2010) Higher treefall rates on slopes and waterlogged soils result in lower 
stand biomass and productivity in a tropical rain forest. J Ecol 98: $106-116$

Fielding JM (1964) Notes on a monterey pine seed orchard on Tallaganda State Forest in New South Wales. Aust For 28:203-206

Gleason CJ, Im J (2012) Forest biomass estimation from airborne LiDAR data using machine learning approaches. Remote Sens Environ 125: 80-91. doi:10.1016/j.rse.2012.07.006

Hawbaker TJ, Keuler NS, Lesak AA, Gobakken T, Contrucci K, Radeloff VC (2009) Improved estimates of forest vegetation structure and biomass with a LiDAR-optimized sampling design. J Geophys Res Biogeosci 114:G00E04. doi:10.1029/2008jg000870

Jenkins JC, Chojnacky DC, Heath LS, Birdsey RA (2003) National scale biomass estimators for United States tree species. For Sci 49:12-35

Junttila V, Finley AO, Bradford JB, Kauranne T (2013) Strategies for minimizing sample size for use in airborne LiDAR-based forest inventory. Forest Ecol Manag 292:75-85. doi:10.1016/j.foreco. 2012.12.019

Kraus K, Pfeifer N (1998) Determination of terrain models in wooded areas with airborne laser scanner data. ISPRS J Photogramm Remote Sens 53:193-203. doi:10.1016/S0924-2716(98)00009-4

Kumar L, Skidmore AK, Knowles E (1997) Modelling topographic variation in solar radiation in a GIS environment. Int J Geogr Inf Sci 11:475-497

LAStools (2014) rapidlasso GmbH. www.rapidlasso.com/. Accessed 14 Mar 2014

Lee W-K, Gadow KV, Chung D-J, Lee J-L, Shin M-Y (2004) DBH growth model for Pinus densiflora and Quercus variabilis mixed forests in central Korea. Ecol Model 176:187-200. doi:10.1016/j. ecolmodel.2003.11.012

Li Y, Wang C, Tang H (2006) Research advances in nutrient runoff on sloping land in watersheds. Aquat Ecosys Health Manag 9:27-32. doi:10.1080/14634980600559379

Li Y, Andersen H-E, McGaughey R (2008) A comparison of statistical methods for estimating forest biomass from light detection and ranging data. West J Appl For 23:223-231

Maltamo M, Bollandsås OM, Næsset E, Gobakken T, Packalén P (2011) Different plot selection strategies for field training data in ALSassisted forest inventory. Forestry 84:23-31. doi:10.1093/forestry/ cpq039

McGaughey RJ (2007) FUSION manual, version 2.90. USDA Forest Service

McGaughey RJ (2013) FUSION/LDV: software for LiDAR data analysis and visualisation, vol Version 3.30. U.S. Department of Agriculture Forest Service, Pacific Northwest Research Station, University of Washington, Seattle

Moore JR (2010) Allometric equations to predict the total above-ground biomass of radiata pine trees. Ann For Sci 67:806. doi:10.1051/ forest $/ 2010042$
Næsset E (1997) Determination of mean tree height of forest stands using airborne laser scanner data. ISPRS J Photogramm Remote Sens 52: $49-56$

Nevo E (2001) Evolution of genome-phenome diversity under environmental stress. Proc Natl Acad Sci U S A 98:6233-6240

Popescu SC (2007) Estimating biomass of individual pine trees using airborne lidar. Biomass Bioenergy 31:646-655. doi:10.1016/j. biombioe.2007.06.022

R Development Core Team (2011) R: a language and environment for statistical computing. R Foundation for Statistical Computing, Vienna

Radiata Pine Breeding Company (RPBC) (2002) Rating the genetic quality of radiata pine. RPBC Information Bulletin No. 1. Rotorua, New Zealand. http://www.rpbc.co.nz/index.htm

Robert A (2003) Simulation of the effect of topography and tree falls on stand dynamics and stand structure of tropical forests. Ecol Model 167:287-303

Ryan PJ, Holmes GI (1986) Geology of Hanging Rock and Nundle State Forests. Technical paper; no. 37. Sydney

Schröder M, Rehrauer H, Seidel K, Datcu M (1998) Spatial information retrieval from remote sensing images - part II: Gibbs Markov random fields. IEEE Trans Geosci Remote Sens 36:1446-1455

Silvergieter MP, Lank DB (2011) Marbled murrelets select distinctive nest trees within old-growth forest patches. Avian Conserv Ecol 6:3

Snowdon P, Woollons RC, Benson ML (1998) Incorporation of climatic indices into models of growth of Pinus radiata in a spacing experiment. New For 16:101-123. doi:10.1023/a:1006524609459

Stage AR, Salas C (2007) Interactions of elevation, aspect, and slope in models of forest species composition and productivity. For Sci 53: 486-492

Turner J, Lambert M, Hopmans P, McGrath J (2001) Site variation in Pinus radiata plantations and implications for site specific management. New For 21:249-282. doi:10.1023/a:1012240720833

Vanclay JK (2009) Tree diameter, height and stocking in even-aged forests. Ann For Sci 66:702

White JC, Wulder MA, Varhola A, Vastaranta M, Coops NC, Cook BD, Pitt D, Woods M (2013) A best practices guide for generating forest inventory attributes from airborne laser scanning data using an area-based approach. For Chron 89:722-723. doi:10. 5558/tfc2013-132

Woollons RC, Snowdon P, Mitchell ND (1997) Augmenting empirical stand projection equations with edaphic and climatic variables. For Ecol Manag 98:267-275. doi:10.1016/S0378-1127(97)00090-X

Worrell R, Malcolm DC (1990) Productivity of Sitka spruce in Northern Britain 2. Prediction from site factors. Forestry 63:119-128

$\mathrm{Xu}$ T, Hutchinson MF (2011) ANUCLIM Version 6.1 User Guide. The Australian National University, Fenner School of Environment and Society, Canberra 